Article

\title{
Nitrate in Groundwater Resources of Hormozgan Province, Southern Iran: Concentration Estimation, Distribution and Probabilistic Health Risk Assessment Using Monte Carlo Simulation
}

\author{
Amin Mohammadpour ${ }^{1}$, Ehsan Gharehchahi ${ }^{1}$, Ahmad Badeenezhad ${ }^{2}$, Iman Parseh ${ }^{2}$, Razieh Khaksefidi ${ }^{1}$, \\ Mohammad Golaki ${ }^{1}$, Reza Dehbandi ${ }^{3}$, Abooalfazl Azhdarpoor ${ }^{1, *}$, Zahra Derakhshan ${ }^{4}$ (D), \\ Jorge Rodriguez-Chueca ${ }^{5}$ (D) and Stefanos Giannakis ${ }^{6, *(D)}$
}

check for updates

Citation: Mohammadpour, A.; Gharehchahi, E.; Badeenezhad, A.; Parseh, I.; Khaksefidi, R.; Golaki, M.; Dehbandi, R.; Azhdarpoor, A.; Derakhshan, Z.; Rodriguez-Chueca, J.; et al. Nitrate in Groundwater Resources of Hormozgan Province, Southern Iran: Concentration Estimation, Distribution and

Probabilistic Health Risk Assessment Using Monte Carlo Simulation. Water 2022, 14, 564. https://doi.org/ $10.3390 /$ w14040564

Academic Editor: Elias Dimitriou

Received: 10 January 2022

Accepted: 8 February 2022

Published: 13 February 2022

Publisher's Note: MDPI stays neutral with regard to jurisdictional claims in published maps and institutional affiliations.

Copyright: (c) 2022 by the authors. Licensee MDPI, Basel, Switzerland. This article is an open access article distributed under the terms and conditions of the Creative Commons Attribution (CC BY) license (https:// creativecommons.org/licenses/by/ $4.0 /)$.
1 Department of Environmental Health Engineering, School of Public Health, Shiraz University of Medical Sciences, Shiraz 7153675541, Iran; amohammadpour@sums.ac.ir (A.M.); gharehchahi_e@sums.ac.ir (E.G.); r.khaksefidi@sums.ac.ir (R.K.); m_golaki@sums.ac.ir (M.G.)

2 Environmental Health Engineering Department, Behbahan Faculty of Medical Science, Behbahan 6361796819, Iran; badienejad-a@ajums.ac.ir (A.B.); iparseh65@behums.ac.ir (I.P.)

3 Environmental Technologies Research Center, Ahvaz Jundishapur University of Medical Sciences, Ahvaz 6135715794, Iran; dehbandi-r@ajums.ac.ir

4 Research Center for Health Sciences, Institute of Health, Shiraz University of Medical Sciences, Shiraz 7153675541, Iran; derakhshz@sums.ac.ir

5 Departamento de Ingeniería Química Industrial y del Medio Ambiente, E.T.S. de Ingenieros Industriales, Universidad Politécnica de Madrid, c/José Gutiérrez Abascal 2, 28006 Madrid, Spain; jorge.rodriguez.chueca@upm.es

6 Unidad Docente Ingeniería Sanitaria, Departamento de Ingeniería Civil: Hidráulica, Energía y Medio Ambiente, E.T.S. de Ingenieros de Caminos, Canales y Puertos, Universidad Politécnica de Madrid, s/n, 28040 Madrid, Spain

* Correspondence: azhdarpoor@sums.ac.ir (A.A.); stefanos.giannakis@upm.es (S.G.)

\begin{abstract}
High nitrate concentration in drinking water has the potential to cause a series of harmful effects on human health. This study aims to evaluate the health risk of nitrate in groundwater resources of Hormozgan province in four age groups, including infants, children, teenagers, and adults, based on the US EPA methodology and Monte Carlo technique to assess uncertainty and sensitivity analysis. A Geographic Information System (GIS) was used to investigate the spatial distribution of nitrate levels in the study area. The nitrate concentration ranged from 0.3 to $30 \mathrm{mg} / \mathrm{L}$, with an average of $7.37 \pm 5.61 \mathrm{mg} / \mathrm{L}$. There was no significant difference between the average concentration of nitrate in all study areas $(p>0.05)$. The hazard quotient $(\mathrm{HQ})$ was less than 1 for all age groups and counties, indicating a low-risk level. The HQ95 for infants and children in the Monte Carlo simulation was 1.34 and 1.22, respectively. The sensitivity analysis findings showed that the parameter with the most significant influence on the risk of toxicity in all age groups was the nitrate content. Therefore, implementing a water resources management program in the study area can reduce nitrate concentration and enhance water quality.
\end{abstract}

Keywords: nitrate pollution; health risk; Monte Carlo simulation; groundwater contamination

\section{Introduction}

Water is vitally important to life and necessary for wellbeing, security, social development, economic growth, and food production [1]. Nowadays, the provision of safe water has become the most critical concern worldwide [2]. Among the possible extraction sites for drinking water supplies, shallow groundwater aquifers are regarded as an adequate, economical, and reliable water source of acceptable quality in many countries [3]. However, groundwater resources are vulnerable to pollutants originating from agricultural development, industrial activities, as well as municipal and agricultural sewage discharge [4]. Land 
use and its coverage can affect groundwater quality [5]. Approximately $63 \%$ of the drinking water of the Iranian people is supplied from groundwater resources, so in some large cities and many rural communities, the only source of drinking water is groundwater [6].

Nitrate is one of the most common contaminants in groundwater resources globally, and its presence can severely hamper clean water availability; high nitrate levels lead to limited reliance on such sources $[7,8]$. Its transmission from source to the aquifer is as follows: Nitrate penetrates groundwater through several sources, including the application of synthetic nitrogen fertilizers and manure, pesticides, septic tank effluents, absorption wells, wastewater effluents, decomposition of dead animals and plants, and unsanitary solid waste disposal [9-11]. Among the issues caused by nitrate, its elevated levels in potable water can cause infant methemoglobinemia (MetHb-Blue Baby Syndrome) and may be associated with the incidence of involuntary abortion and infertility problems. In MetHb disease, nitrate produces methemoglobin and reduces the blood oxygen; therefore, the baby turns blue (Cyanotic) [12-14]. It was shown that women who consume groundwater with high nitrate concentrations during pregnancy are at higher risk of having a child with congenital abnormalities [15]. Furthermore, nitrate is the precursor in the formation of nitrosamines (potent carcinogens), raising the risk of various types of cancer, such as nasopharynx, esophagus, stomach, pancreas, colorectal, and brain [16,17].

Based on the World health organization (WHO) guidelines for drinking water quality, the value for nitrate concentration in drinking water to protect the health of the susceptible subpopulation, bottle-fed infants, is $50 \mathrm{mg} / \mathrm{L}$ in the form of $\mathrm{NO}_{3}{ }^{-}[18,19]$. Hence, the responsible authorities must assess the human health risk of nitrate via ingestion of drinking water in different regions and provide groundwater resources management strategies to reduce the adverse health effects of nitrate on different age groups such as infants, teenagers, children, and adults $[20,21]$.

A high nitrate level in groundwater resources is a severe water resources management issue in many urban areas of Iran, such as Tehran, Mashhad, Zahedan, and Qom [22]. Hormozgan Province is one of the arid areas of Iran, with an average rainfall of less than $200 \mathrm{~mm}$. Furthermore, most rivers are seasonal, and because of various environmental pollutants, surface water quality is poor. Consequently, groundwater resources are applied for drinking, agriculture, and industry; therefore, monitoring groundwater quality is indispensable to protect consumers and ensure their safety.

An effective approach to water resources management is to analyze land-use effects on the spatial distribution of pollutants and, consequently, water quality. Various software programs are used to monitor groundwater and evaluate the risks associated with pollutants. Geographical Information Systems (GIS) are used effectively in analyzing, interpolation, spatial data display, and monitoring various environmental pollutants [23,24].

Given the broad population exposed to pollutants (nitrates) in this province's drinking water, this study aims to assess the health risk of nitrate in the groundwater:

1. We set up a grid of nitrate measurements in groundwater of the Hormozgan region, establishing its spatial distribution and occurrence. Following this, we queried the non-carcinogenic threats by assessing the Estimated Daily Intake (EDI) and Hazard Quotients (HQ) for nitrate consumption in four age groups, including infants, children, teenagers, and adults.

2. We used the Monte Carlo simulation method to account for the intrinsic uncertainty.

3. Sensitivity analysis indicated the relationship between nitrate consumption and toxicity and the main alleviation factors.

\section{Materials and Methods}

\subsection{Study Area}

Hormozgan province is located in the south of Iran and north of the Persian Gulf and Oman Sea. The population of Hormozgan province is 1.7 million. It is placed at the northern latitude of $25^{\circ} 24^{\prime}$ to $28^{\circ} 57^{\prime}$ and the eastern longitude of $53^{\circ} 41^{\prime}$ to $59^{\circ} 15^{\prime}$. The area of Hormozgan province is about $68,000 \mathrm{~km}^{2}$, with 14 islands in the Persian Gulf. The area 
has temperate climate conditions and is warm and humid all year round [25]. The area of Hormozgan agricultural lands is $1560 \mathrm{~km}^{2}$, with an annual production of 2.7 million tons of horticultural and agricultural products. About $19 \%$ of the population of Hormozgan province is active in the agricultural sector and its subdivisions, including fisheries. This province has two sub-basins (Bandar Sadij and Kalmehran, which is part of the Persian Gulf and Oman Sea watershed), which has 65 groundwater aquifers. Most of the population also lives along the coast, where there are 20 aquifers [26]. Figure 1 show Iran's locations in the world and the locations of Hormozgan province in Iran.

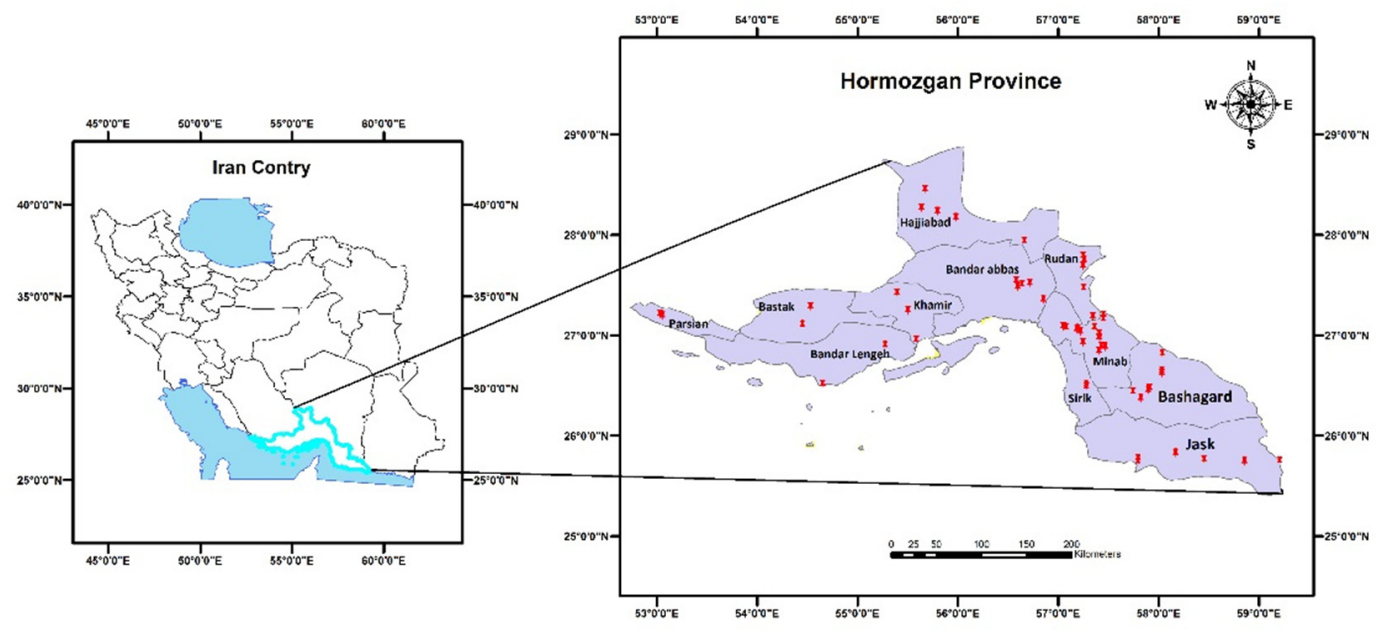

Figure 1. Location of Iran in the world and Hormozgan province in Iran.

\subsection{Sample Collection}

Since the present study is a cross-sectional investigation (summer season-10 August 2019 to 25 August 2019), groundwater samples were randomly taken from 54 locations in 11 counties of Hormozgan province except for its islands $[27,28]$. One-L polyethylene bottles (Merck company, Darmstadt, Germany) were used for the collection of samples. Before sampling, the bottles were washed with the well water to be extracted. Samples were shipped to the laboratory immediately after recording the characteristics of sampling places and times. Nitrate levels were analyzed employing a spectrophotometer (Hach DR5000-Method 10049; HACH company, Loveland, CO, USA) based on ultraviolet absorption at $220 \mathrm{~nm}$. In order to eliminate the interference of organic matter, the second measurement was performed at $275 \mathrm{~nm}$ to correct the amount of nitrate, and their difference was reported as nitrate concentration [29]. All measurements and analyses related to the parameters were performed accurately. For greater accuracy and QA/QC, all analyses were repeated twice $(\mathrm{LOQ}=0.2$ and LOD $=0.1)$. Additionally, two samples of distilled water were used as controls for further quality control of the experimental results.

\subsection{Exposure Assessment and Risk Estimation}

Assessing health risks is an integral part of the decision-making process in water sources. Generally, the health risk assessment estimates the nature and probability of vulnerability to human health associated with exposure to chemicals in the environment [30,31]. A deterministic approach in estimating the potential health hazard of chemicals is to apply the methodology provided by the United States Environmental Protection Agency (US EPA) for health risk methodology. In this technique, a unique value is assigned to each input parameter (e.g., chemical concentration), and a single value is estimated for carcinogenic or non-carcinogenic health risks. The health risk assessment was carried out according to these USEPA guidelines, and the following equation was applied to compute the exposure assessment for Hormozgan province residents [32,33]:

$$
\mathrm{EDI}=\frac{\mathrm{C}_{\mathrm{f}} \times \mathrm{C}_{\mathrm{d}}}{\mathrm{B}_{\mathrm{w}}}
$$


where EDI is the estimated daily intake $\left(\mathrm{mg} / \mathrm{kg} /\right.$ day); $\mathrm{C}_{\mathrm{f}}$ is the concentration of nitrate in drinking water $(\mathrm{mg} / \mathrm{L}) ; \mathrm{C}_{\mathrm{d}}$ is the average drinking water consumption per day (L), and BW is the body weight $(\mathrm{kg})$.

The hazard quotient was computed using the following equation:

$$
\mathrm{HQ}=\frac{\mathrm{EDI}}{\mathrm{RfD}}
$$

$\mathrm{RfD}$ is the oral reference dose ( $\mathrm{mg} / \mathrm{BW} \mathrm{kg} /$ day) in this equation. The HQ indicates the level to which adverse health effects are not expected. If the $H Q>1$, it is expected that exposure may cause adverse effects on human health [34,35]. Table 1 present the values of the selected parameters used to assess health risks.

Table 1. Parameters used for health risk assessment in groundwater of Hormozgan province counties, Iran.

\begin{tabular}{|c|c|c|c|c|c|c|c|}
\hline Parameters & Unit & $\begin{array}{l}\text { Probability } \\
\text { Distribution }\end{array}$ & $\begin{array}{l}\text { Infants } \\
(<2 \text { Year) }\end{array}$ & $\begin{array}{l}\text { Children } \\
\text { (2-10 Year) }\end{array}$ & $\begin{array}{l}\text { Teenagers } \\
\text { (10-18 Year) }\end{array}$ & $\begin{array}{c}\text { Adults } \\
\text { (>18 Year) }\end{array}$ & References \\
\hline $\mathrm{Cf}$ & $\mathrm{mg} / \mathrm{L}$ & Log-normal & - & - & - & - & Current study \\
\hline $\mathrm{Cd}$ & L/day & Log-normal & $0.61 \pm 0.27$ & $1.25 \pm 0.57$ & $1.58 \pm 0.69$ & $1.95 \pm 0.64$ & Adapted from [36] \\
\hline BW & $\mathrm{kg}$ & Log-normal & $7.98 \pm 1.02$ & $16.41 \pm 3.78$ & $39.83 \pm 10.16$ & $77.45 \pm 13.6$ & Adapted from [37] \\
\hline RfD & $\begin{array}{l}\mathrm{mg} / \mathrm{BW} \\
\mathrm{kg} / \text { day }\end{array}$ & - & 1.6 & 1.6 & 1.6 & 1.6 & Adapted from [38] \\
\hline
\end{tabular}

Uncertainties are critical in health risk assessment, resulting from a lack of specific knowledge, insufficient data, and variability [39]. In order to assess various random scenarios, the Monte Carlo simulation approach is often employed; Monte Carlo is a computational algorithm based on thousands of random sampling iterations that typically determine quantitative uncertainty by understanding a probability distribution (normal, lognormal, uniform, gamma distribution) for the involved parameters [40]. Besides, sensitivity analysis is a technique used to determine the impact of an independent variable on a particular output variable (dependent variable) in a model [31].

\subsection{Data Probability Distribution and Data Analysis}

In the present study, Microsoft Excel 2013, R software version 6.3.2, and Oracle Crystal Ball software version 11.1.2.3 were utilized for statistical analysis, normality test, hierarchical cluster analysis (HCA), Monte Carlo simulation, and sensitivity analysis, respectively. The Shapiro-Wilk test was used to evaluate the normality of data. The inverse distance weighting (IDW) technique was employed in the ESRI ArcGIS software version 10.8 to estimate the nitrate concentration values for un-sampled areas.

\section{Results and Discussion}

\subsection{Results of Descriptive Analysis}

Firstly, an investigation involving onsite measurements of nitrate levels in various counties of the Hormozgan province was performed, and the results are summarized in Table 2 . The mean value for nitrate concentration in drinking water of the study area was $7.37 \pm 6.51 \mathrm{mg} / \mathrm{L}$. The highest and lowest nitrate concentration in the Hormozgan province was encountered in the Parsian and Rudan country, with 30 and $0.3 \mathrm{mg} / \mathrm{L}$, respectively (Table 2). The high nitrate concentration in the Yord-e-Qasemali region compared to other regions could be due to excessive use of nitrate fertilizers in agriculture taking place locally or sewage leakage. Generally, nitrate levels were below the WHO guideline value (45 mg/L) in all counties in Hormozgan province. Our results fall within those previously measured; in a study conducted by Mirzaei et al. in the Hashtbandi region of Hormozgan province, the mean, highest, and lowest nitrate concentration in groundwater was $17.5( \pm 6.6), 33.5$, and $6 \mathrm{mg} / \mathrm{L}$, respectively [41]. 
Table 2. Nitrate concentration in different sampling places in Hormozgan province.

\begin{tabular}{|c|c|c|c|}
\hline NO. & Counties & Site & Nitrate Concentration $(\mathrm{mg} / \mathrm{L})$ \\
\hline 1 & Jask & Negar-e Bala & 3.6 \\
\hline 2 & Jask & Saran-e Barshaku & 2.2 \\
\hline 3 & Jask & Kiai & 1 \\
\hline 4 & Jask & Shahrak-e Gabrik & 3.8 \\
\hline 5 & Jask & Gazdan & 2.5 \\
\hline 6 & Jask & Hangestan & 1 \\
\hline 7 & Bashagard & Ahun & 4.3 \\
\hline 8 & Bashagard & Behtish & 9.9 \\
\hline 9 & Bashagard & Khomeyni Shahr & 1 \\
\hline 10 & Bashagard & Darreh-ye Murt & 7.7 \\
\hline 11 & Bashagard & Zehbodi & 2.5 \\
\hline 12 & Bashagard & konarejadid & 3.8 \\
\hline 13 & Bashagard & Grough & 7.4 \\
\hline 14 & Minab & Beneh Kan & 1.8 \\
\hline 15 & Minab & Mojtame-ye Emam & 10.6 \\
\hline 16 & Minab & Zartuji & 13.2 \\
\hline 17 & Minab & Sarmazegh & 7.6 \\
\hline 18 & Minab & Jafarabad & 7.4 \\
\hline 19 & Minab & Shivehi & 5.2 \\
\hline 20 & Minab & konarejadid(well6) & 3.4 \\
\hline 21 & Minab & konarejadid(well5) & 3.5 \\
\hline 22 & Minab & Kahurtak & 6.6 \\
\hline 23 & Minab & Gavajag & 4.5 \\
\hline 24 & Minab & Owdui & 7.5 \\
\hline 25 & Minab & Bondar & 9.3 \\
\hline 26 & Minab & Posht Kalat & 16.3 \\
\hline 27 & Minab & tom parian & 7 \\
\hline 28 & Sirik & Ravang(well1) & 5.5 \\
\hline 29 & Sirik & Ravang(well2) & 8.2 \\
\hline 30 & Sirik & Ravang(well3) & 6.8 \\
\hline 31 & Rudan & Bajani & 13.8 \\
\hline 32 & Rudan & Bagh Narges & 2.2 \\
\hline 33 & Rudan & poshtebanan & 18.3 \\
\hline 34 & Rudan & Palur & 6.8 \\
\hline 35 & Rudan & Chiromabad & 0.3 \\
\hline 36 & Bandar Abbas & Bohregh & 17.7 \\
\hline 37 & Bandar Abbas & Takht & 12 \\
\hline 38 & Bandar Abbas & Hasan Langi-ye Bala & 5.1 \\
\hline 39 & Bandar Abbas & Gishan & 7.5 \\
\hline 40 & Bandar Abbas & Moqsam & 8.5 \\
\hline 41 & Hajjiabad & Dar Agah & 7.7 \\
\hline 42 & Hajjiabad & Sar-e Gaz-e Ahmadi & 16.4 \\
\hline 43 & Hajjiabad & Siruiyeh & 6.7 \\
\hline 44 & Hajjiabad & Baynuj & 13.8 \\
\hline 45 & Hajjiabad & Chaleh Murt & 11.4 \\
\hline 46 & Khamir & Bastu(well2) & 1.6 \\
\hline 47 & Khamir & Bastu(mineral spring) & 3.3 \\
\hline 48 & Khamir & Berkeh-ye Soltan & 15.5 \\
\hline 49 & Bastak & Harang & 8 \\
\hline 50 & Bastak & Gowd Kaz & 4.2 \\
\hline 51 & Parsian & Parsian & 4.5 \\
\hline 52 & Parsian & Yord-e Qasemali & 30 \\
\hline 53 & Bandar Lengeh & Bostaneh & 7.2 \\
\hline 54 & Bandar Lengeh & Dezhgan & 0.5 \\
\hline
\end{tabular}

\subsection{Occurrence and Spatial Distribution of Nitrate}

An approach to water resources management is to analyze land-use effects on the spatial distribution of pollutants and, consequently, water quality. A variety of software 
programs are currently available to monitor groundwater and evaluate the risks associated with pollutants. In general, using GIS software, can effectively analyze, intercept, display spatial data, and monitor various environmental pollutants [39]. Our results obtained by ESRI ArcGIS are presented in Figure 2. Figure 2 show the spatial distribution of nitrate concentration in the drinking water of Hormozgan province. The highest nitrate values were observed in the west of Hormozgan in Parsian County. However, there is a patchy distribution of high nitrate levels in the province's center in Bandar abbas, Rudan, and Hajiabad countries. Sewage discharge in Bandar Abbas county and routine nitrate fertilizers in the agricultural sector in Parsian, Hajiabad, and Rudan counties may be the reason for high nitrate in these areas. High nitrate levels in the groundwater may also be due to the leaching of animal wastes, especially in rural areas. Most of the excreta of the domestic animals are not properly disposed of, and excreta, dung, and urine produced by animals constitute a potential source of nitrate contamination in the groundwater. Therefore, agricultural management and sewage disposal in this province should be considered.

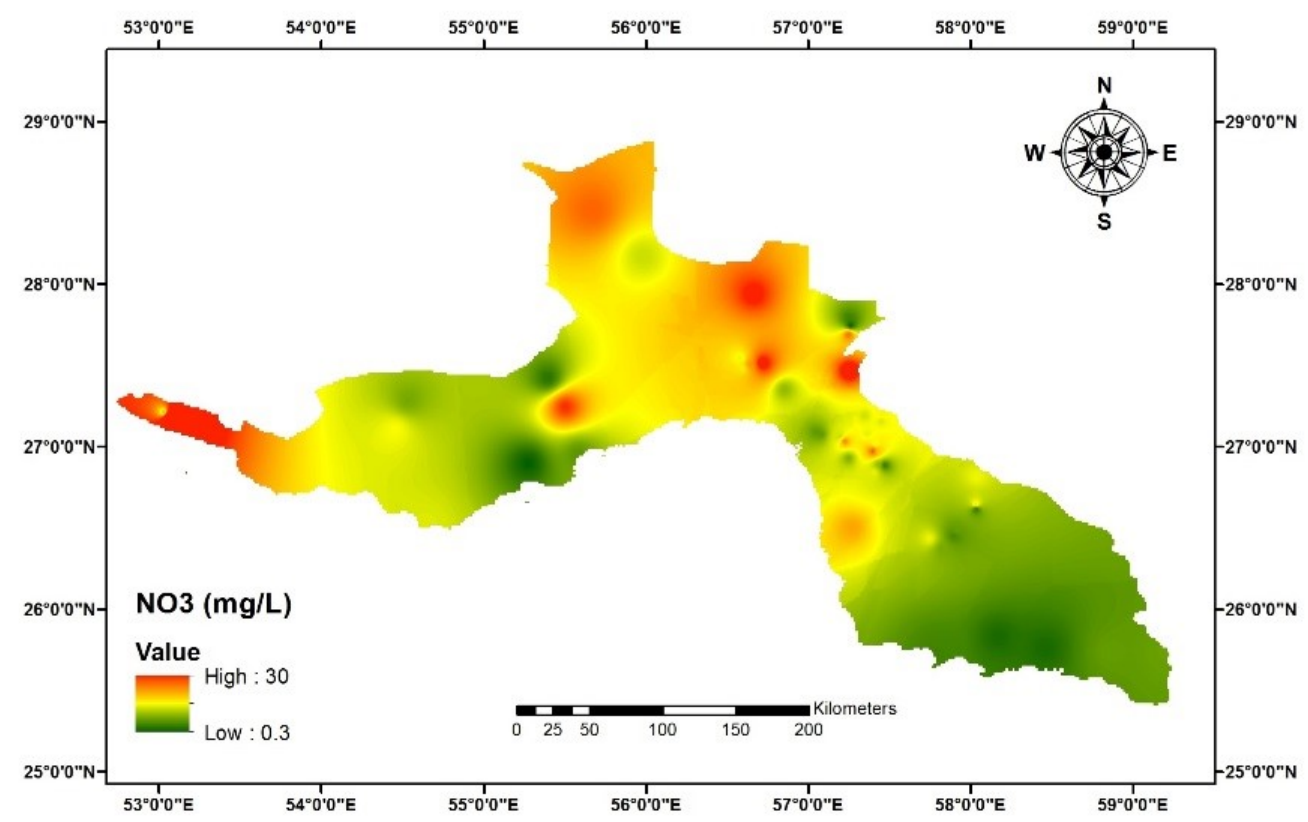

Figure 2. Spatial distribution of nitrate concentration in the drinking water of Hormozgan province.

Further analysis of this behavior by the Shapiro-Wilk normality test showed that the distribution of nitrate concentration in Hormozgan province is not normal $(p<0.05)$. The comparison of the mean values of nitrate concentration in the country of Hormozgan province (Figure 3 ) showed that, with a 95\% confidence interval, there is no significant difference in mean levels of nitrate in different counties $(p<0.05)$. The hierarchical cluster analysis (HCA) is an algorithm that sequentially pairs variables based on their similarity with the other group's variables. In the current study, HCA showed that the Yord-eQasemali region in terms of nitrate concentration had a slight similarity with other regions (Figure 4).

\subsection{Exposure Assessment and Risk Estimation Results}

Investigating the association between nitrate levels in potable water and non-cancer risk is a question to consider in the study area. In order to assess the non-carcinogenic risks from nitrate presence in water, the EDI and HQ for infants, children, teenagers, and adults via ingestion exposure were calculated [42]. The fractionation of the population was performed according to the potential risks each age group may face if exposed to high nitrate levels. The EDI and HQ results analyzed in different age groups and per region are illustrated in Figures 5 and 6, respectively. The highest EDI at $1.32 \mathrm{mg} / \mathrm{kg} / \mathrm{day}$ was associated with the town of Parsian for infants. The EDI for children, teenagers, and adults 
ranged between 0.18-1.3, 0.09-0.7, and 0.06-0.4 mg/kg/day. Consequently, the calculated HQ values were less than 1 for all regions and all age groups in this study. More specifically, the HQ values for infants throughout the Hormozgan province were close to each other, while the HQs for both infants and children were two-fold higher than teenagers and 2.9 times higher than adults.

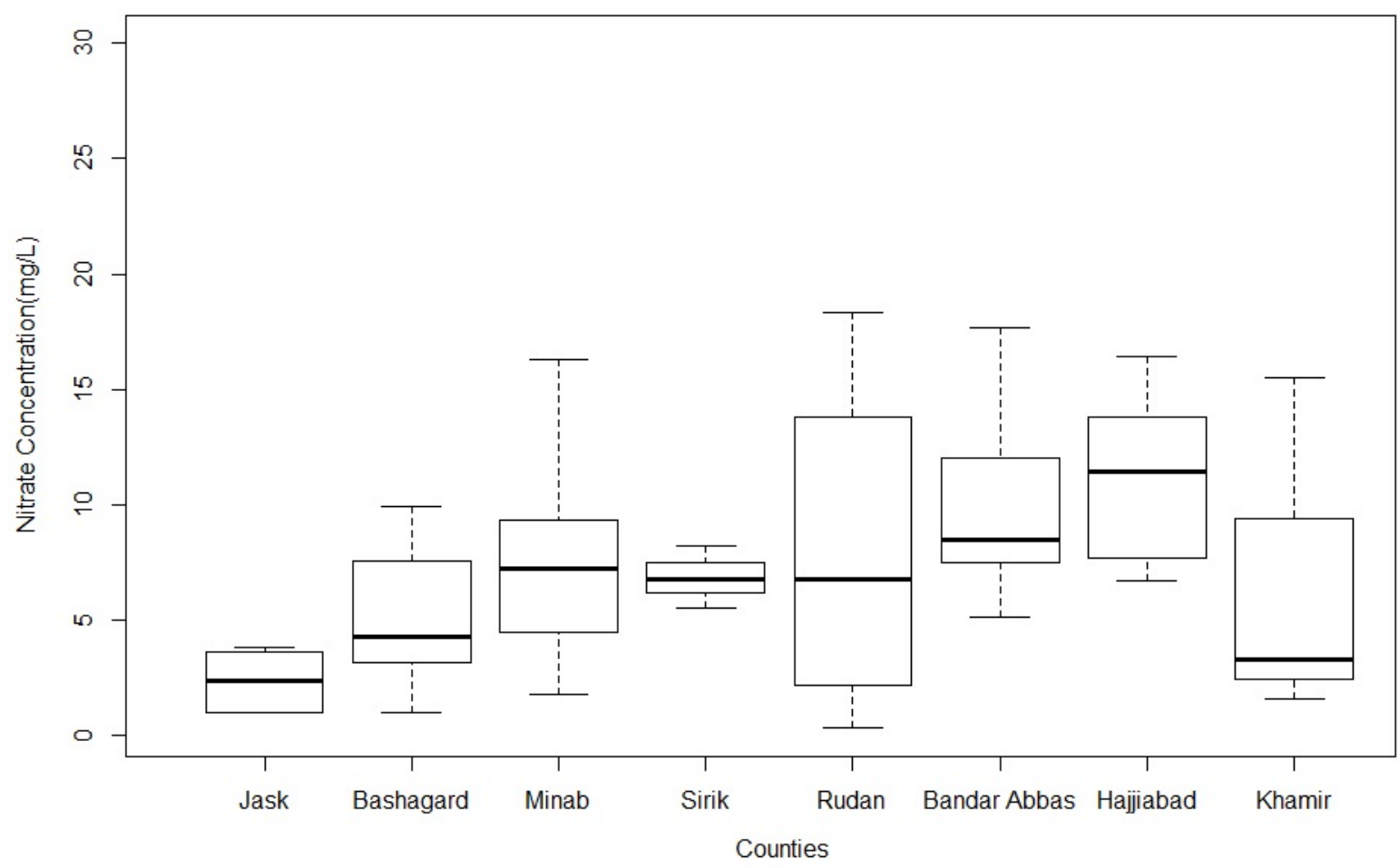

Figure 3. Box plots and Kruskal-Wallis test results for different counties of Hormozgan province.

Cluster Dendrogram

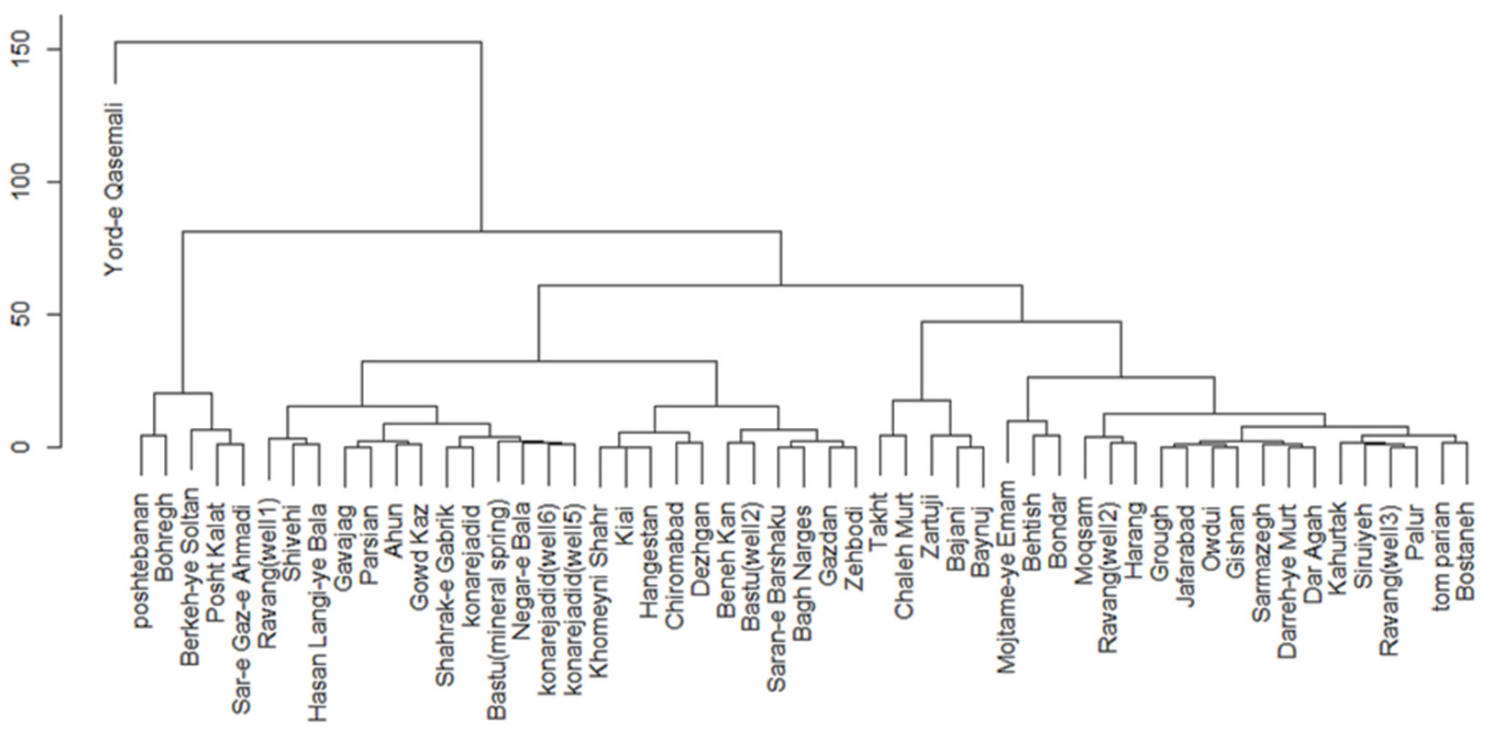

Location

Figure 4. The hierarchical cluster analysis for the study area. 


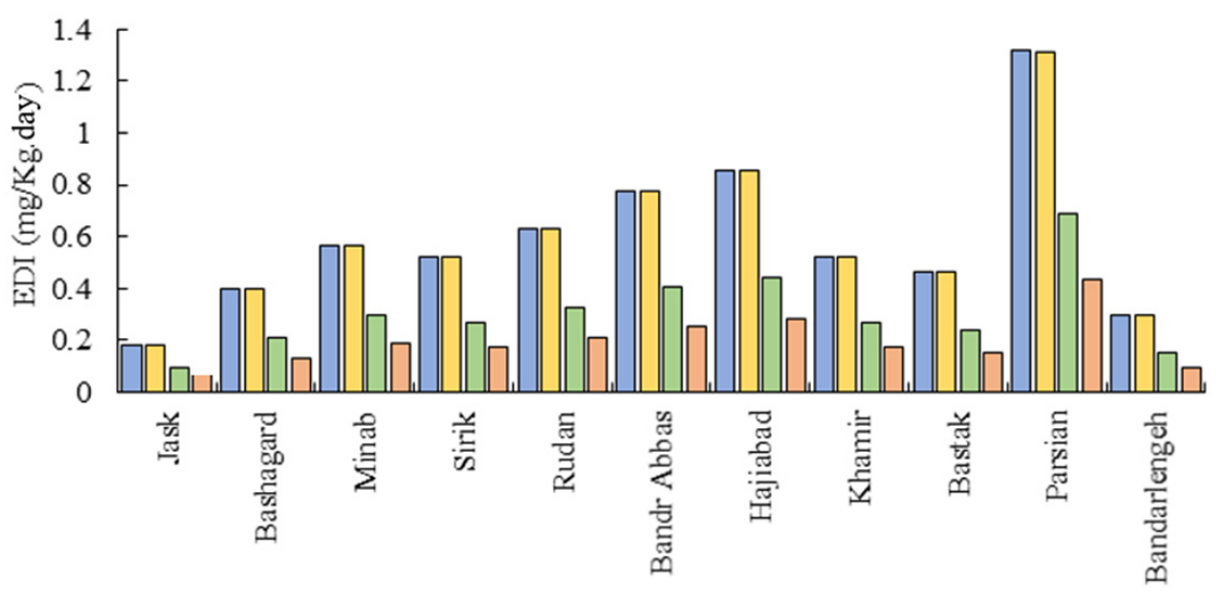

Hormozgan Cities

Figure 5. EDI Values for exposure to nitrate in cities of Hormozgan province in different age groups.

$\square$ Infants $\square$ Childeren $\square$ Teenagers $\square$ Adults

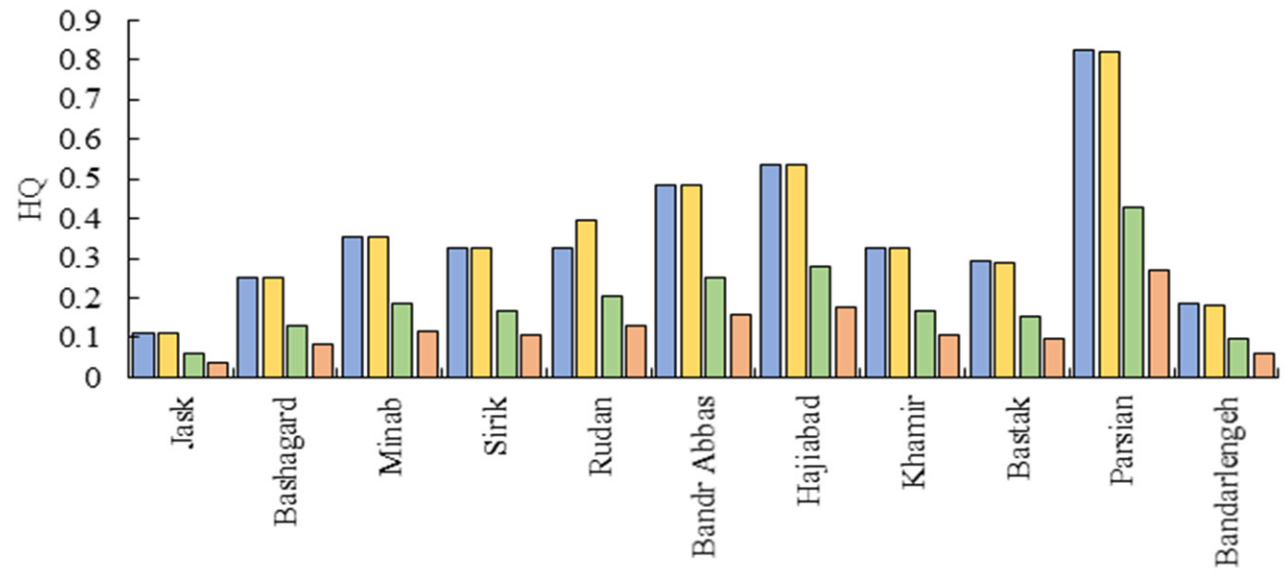

Hormozgan Cities

Figure 6. HQ Values for exposure to nitrate in cities of Hormozgan province in different age groups.

The current work results for HQ are consistent with the results of Qasemi et al. in the rural regions of Gonabad and Bajestan, Iran [43]. Since it was found that the HQ values were less than 1 for all age groups and counties, we suggest that exposure to nitrate through drinking water in the long term does not appear to threaten human health. However, infants are at more risk for the non-carcinogenic effect of nitrate as they consume more water per unit of body weight than teenagers and adults [44].

Furthermore, Gholami et al. conducted a study on groundwater nitrate contamination and its human health risk in the Ilam city, Iran. They also showed that children were at higher risk than adults [45]. The underlying reason for extensive research on this indicator is that several epidemiological studies have demonstrated a strong (positive) correlation between nitrate exposure and cancer risk. Nitrate in the drinking water of the United States and the United Kingdom was associated with colon and bladder cancer [46,47].

Therefore, investigating the association between nitrate levels in potable water and cancer incidence is a question to consider in the study area. Table 3 shows the comparisons between nitrate and HQ concentrations for the different provinces of Iran. 
Table 3. Comparative study of nitrate contamination in groundwater of Iran country.

\begin{tabular}{|c|c|c|c|c|}
\hline Province & Number of Samples & $\mathrm{NO}_{3}$ Concentration $(\mathrm{mg} / \mathrm{L})$ & HQ & Ref. \\
\hline Kurdistan & 60 & $36.06 \pm 14.32$ & $\begin{array}{c}\text { Infants }=0.90 \\
\text { Children }=1.17 \\
\text { Teenagers }=0.90 \\
\text { Adults }=0.70\end{array}$ & Adapted from [48] \\
\hline Hamadan & 26 & $24.02 \pm 12.11$ & $\begin{array}{c}\text { Children }=0.854 \\
\text { Adults }=0.529 \\
\text { Infants }=1.79\end{array}$ & Adapted from [49] \\
\hline Razavi Khorasan & 30 & $5.7-25.4($ mean $=12.58)$ & $\begin{array}{l}\text { Children }=1.68 \\
\text { Adults }=0.64\end{array}$ & Adapted from [50] \\
\hline Golestan & 58 & $\begin{array}{c}\text { Wells }=1-36(\text { mean }=16.8) \\
\text { Springs }=5-51(\text { mean }=22.7)\end{array}$ & $\begin{array}{c}\text { Infants }=0.94 \\
\text { Children }=0.88 \\
\text { Adults }=0.33 \\
\text { Infants }=0.56\end{array}$ & Adapted from [43] \\
\hline Kurdistan & 45 & $22.42 \pm 11.44$ & $\begin{array}{c}\text { Children }=0.72 \\
\text { Teenagers }=0.56 \\
\text { Adults }=0.43 \\
\text { Children }=0.75\end{array}$ & Adapted from [51] \\
\hline Fars & 70 & Cold season $=26.95 \pm 17.03$ & $\begin{array}{c}\text { Teenagers }=0.61 \\
\text { Adults }=0.66 \\
\text { Children }=0.57\end{array}$ & Adapted from [10] \\
\hline & & Warm season $=24.88 \pm 15.88$ & $\begin{array}{l}\text { Teenagers }=0.47 \\
\text { Adults }=0.5 \\
\text { Infants }=0.33\end{array}$ & \\
\hline Sistan, and Baluchistan & 66 & $6.15 \pm 6.15$ & $\begin{array}{c}\text { Children }=0.31 \\
\text { Teenagers }=0.31 \\
\text { Adults }=0.30 \\
\text { Infants }=0.35\end{array}$ & Adapted from [52] \\
\hline Hormozgan & 54 & $7.37 \pm 5.61$ & $\begin{array}{c}\text { Children }=0.35 \\
\text { Teenagers }=0.18 \\
\text { Adults }=0.12\end{array}$ & This study \\
\hline
\end{tabular}

\subsection{Results of the Probabilistic Approach}

In the deterministic approach (US EPA method), fixed values estimate health risk, but inherent uncertainty was not considered. Therefore, a probabilistic approach was employed using the Monte Carlo technique to address the uncertainty. Figure 7 show the health risk assessment results using the Monte Carlo simulation. The Monte Carlo simulation results show that the HQ50 values for all age groups were below 1, indicating that prolonged exposure to nitrate in drinking water could not threaten the population health in Hormozgan cities. Besides, the HQ95 values for infants, children, teenagers, and adults were $1.34,1.22,0.77$, and 0.40 , respectively. Therefore, based on HQ95 results, exposure to nitrate levels of $21.0 \mathrm{mg} / \mathrm{L}$ or more in drinking water can threaten infants' and children's health, respectively.

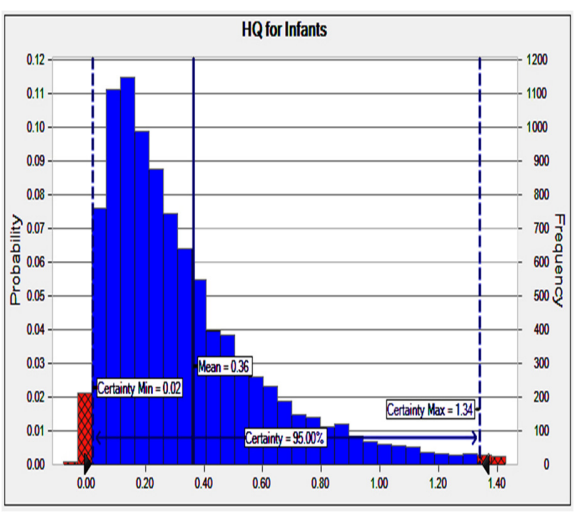

(a)

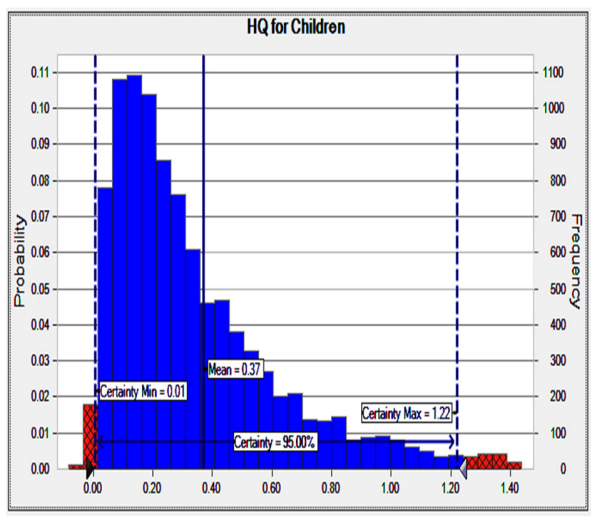

(b)

Figure 7. Cont. 


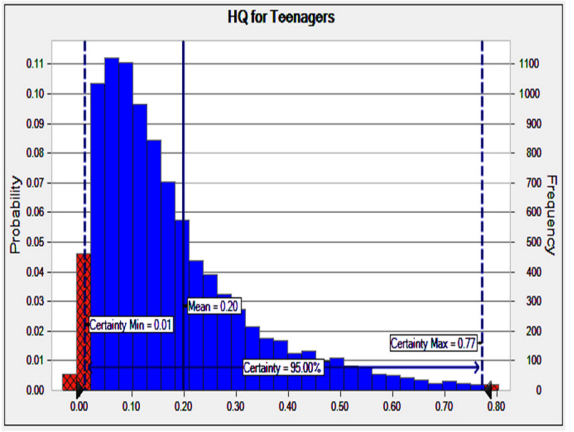

(c)

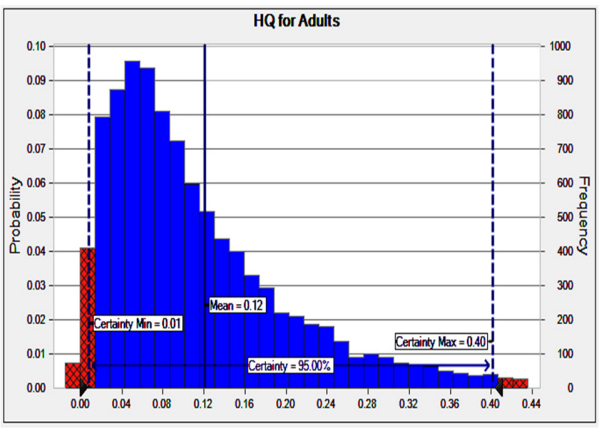

(d)

Figure 7. HQ Histogram: (a) Infants; (b) Children; (c) Teenagers; (d) Adults.

The sensitivity analysis results showed that nitrate concentration and water consumption positively influenced health risk (Figure 8). In contrast, the toxicity of nitrate was adversely affected by body weight. Climate conditions and physical activities can increase the nitrate non-carcinogenic risk due to enhanced water consumption. Hence, the result may be an increased risk of nitrate exposure from drinking water.

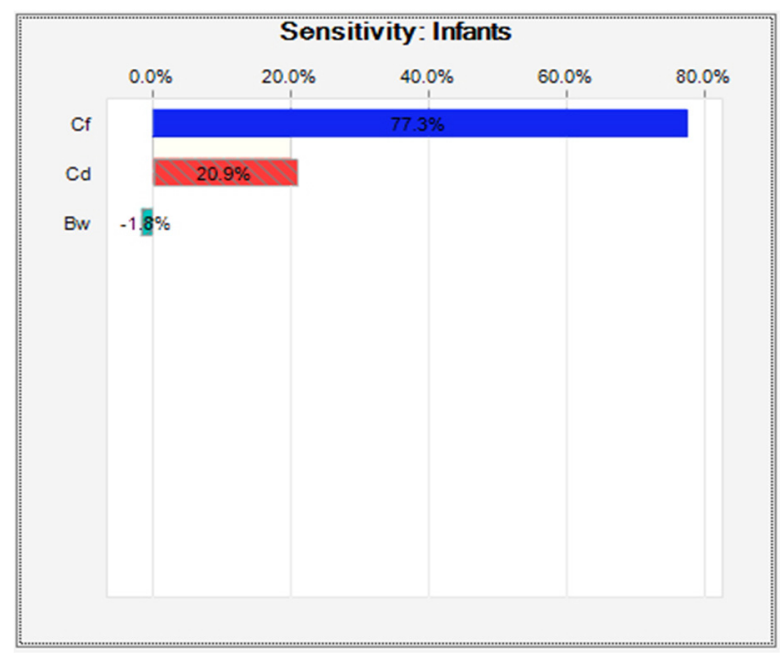

(a)

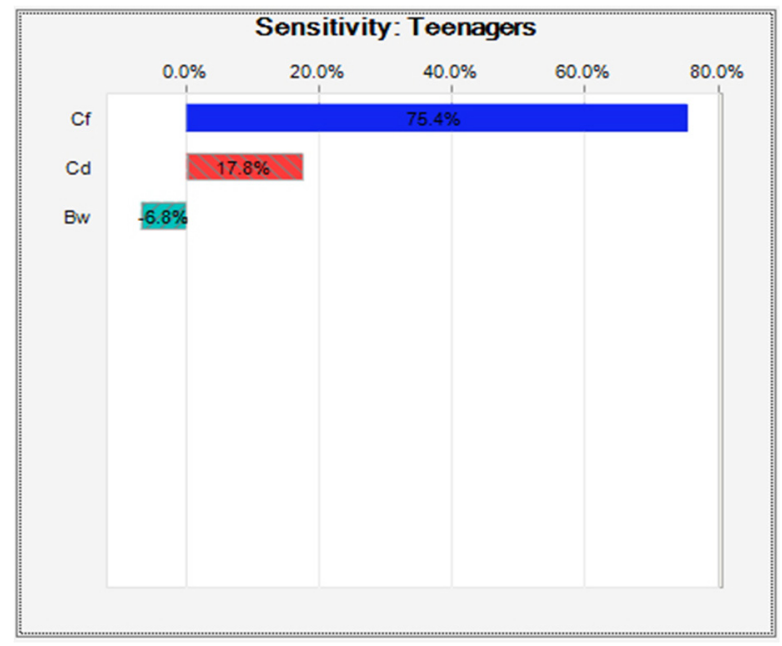

(c)

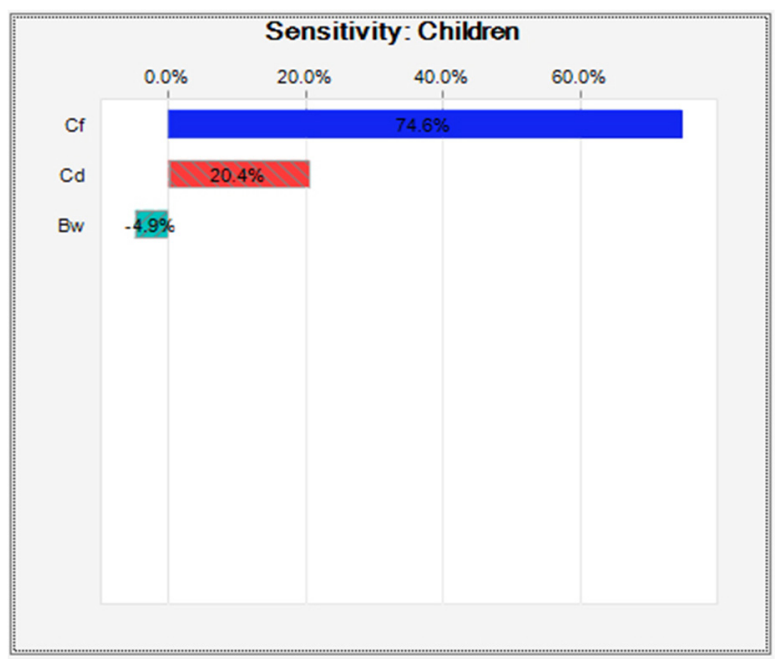

(b)

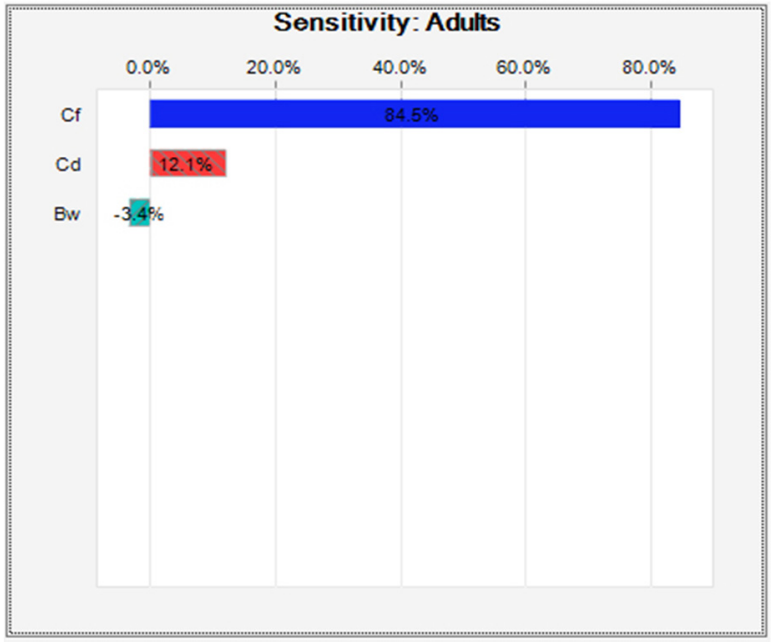

(d)

Figure 8. Results of sensitivity analysis: (a) Infants; (b) Children; (c) Teenagers; (d) Adults. 


\section{Conclusions}

This study aimed to evaluate the health risk of nitrate in drinking water in Hormozgan province. Our findings showed that the nitrate levels were lower than the WHO guideline, which constitutes excellent news for the burdened water resources of this arid region and the end-consumers. Additionally, the deterministic approach for health risk assessment demonstrated that the HQ values were below 1 for all age groups in all regions, indicating a low possibility of non-carcinogenic risk. However, the probabilistic approach results revealed that HQ95 was above 1 for infants and children. Hence, concerning exposure to nitrate in drinking water, we estimate that a threshold concentration of $21.0 \mathrm{mg} / \mathrm{L}$ or more can threaten infants' and children's health, howbeit, the WHO recommends nitrate concentrations below $50 \mathrm{mg} / \mathrm{L}$.

Furthermore, the sensitivity analysis findings revealed that the levels of nitrate and water consumption positively impacted the health risk. Therefore, it is imperative to implement a water resources management program in the study area, as such an action can actively reduce nitrate concentration and enhance drinking water quality for the local population.

Author Contributions: A.M. and A.A.: conceptualization, writing-original draft, supervision; E.G. and R.K.: analysis and interpretation, software; A.B. and I.P.: conceptualization, validation; M.G. and R.D.: experimentation, methodology; Z.D., J.R.-C. and S.G.: review and editing. All authors have read and agreed to the published version of the manuscript.

Funding: The funding of this project (Research Intercept Code: 22888) was supported by Shiraz University of Medical Sciences.

Institutional Review Board Statement: Not needed or available.

Informed Consent Statement: Not available or needed for this study.

Data Availability Statement: Data can be accessed upon request to the corresponding author.

Acknowledgments: The authors thank the cooperation of Shiraz University of Medical Sciences.

Conflicts of Interest: The authors declare no conflict of interest.

$\begin{array}{ll}\text { Abbreviations } \\ \text { BW } & \text { Body Weight } \\ \text { EDI } & \text { Estimated Daily Intake } \\ \text { GIS } & \text { Geographic Information System } \\ \text { HCA } & \text { Hierarchical Cluster Analysis } \\ \text { HQ } & \text { Hazard Quotient } \\ \text { IDW } & \text { Inverse Distance Weighting } \\ \text { LOD } & \text { limit of Detection } \\ \text { LOQ } & \text { limit of Quantification } \\ \text { US EPA } & \text { United States Environmental Protection Agency } \\ \text { WHO } & \text { World Health Organization }\end{array}$

\section{References}

1. Gohar, A.A.; Cashman, A. A methodology to assess the impact of climate variability and change on water resources, food security and economic welfare. Agric. Syst. 2016, 147, 51-64. [CrossRef]

2. Tiwari, A.K.; Singh, A.K. Hydrogeochemical investigation and groundwater quality assessment of Pratapgarh district, Uttar Pradesh. J. Geol. Soc. India 2014, 83, 329-343. [CrossRef]

3. Chen, J.; $\mathrm{Wu}, \mathrm{H} . ;$ Qian, H. Groundwater nitrate contamination and associated health risk for the rural communities in an agricultural area of Ningxia, northwest China. Expo. Health 2016, 8, 349-359. [CrossRef]

4. Serio, F.; Miglietta, P.P.; Lamastra, L.; Ficocelli, S.; Intini, F.; De Leo, F.; De Donno, A. Groundwater nitrate contamination and agricultural land use: A grey water footprint perspective in Southern Apulia Region (Italy). Sci. Total Environ. 2018, 645, 1425-1431. [CrossRef] [PubMed]

5. Tiwari, A.K.; Suozzi, E.; Fiorucci, A.; Lo Russo, S. Assessment of groundwater geochemistry and human health risk of an intensively cropped alluvial plain, NW Italy. Hum. Ecol. Risk Assess. Int. J. 2021, 27, 825-845. [CrossRef] 
6. Sajedi-Hosseini, F.; Malekian, A.; Choubin, B.; Rahmati, O.; Cipullo, S.; Coulon, F.; Pradhan, B. A novel machine learning-based approach for the risk assessment of nitrate groundwater contamination. Sci. Total Environ. 2018, 644, 954-962. [CrossRef]

7. Nolan, J.; Weber, K.A.J.E.S.; Letters, T. Natural uranium contamination in major US aquifers linked to nitrate. Environ. Sci. Technol. Lett. 2015, 2, 215-220. [CrossRef]

8. Wagh, V.M.; Panaskar, D.B.; Mukate, S.V.; Aamalawar, M.L.; Laxman Sahu, U. Nitrate associated health risks from groundwater of Kadava river basin Nashik, Maharashtra, India. Hum. Ecol. Risk Assess. Int. J. 2020, 26, 654-672. [CrossRef]

9. Liu, G.; Wu, W.; Zhang, J. Regional differentiation of non-point source pollution of agriculture-derived nitrate nitrogen in groundwater in northern China. Agric. Ecosyst. Environ. 2005, 107, 211-220. [CrossRef]

10. Badeenezhad, A.; Radfard, M.; Passalari, H.; Parseh, I.; Abbasi, F.; Rostami, S. Factors affecting the nitrate concentration and its health risk assessment in drinking groundwater by application of Monte Carlo simulation and geographic information system. Hum. Ecol. Risk Assess. Int. J. 2021, 27, 1458-1471. [CrossRef]

11. Lee, C.-M.; Hamm, S.-Y.; Cheong, J.-Y.; Kim, K.; Yoon, H.; Kim, M.; Kim, J. Contribution of nitrate-nitrogen concentration in groundwater to stream water in an agricultural head watershed. Environ. Res. 2020, 184, 109313. [CrossRef]

12. Shuval, H.I.; Gruener, N. Infant methemoglobinemia and other health effects of nitrates in drinking water. In Proceedings of the Conference on Nitrogen as a Water Pollutant; The Danish National Committee of the International Association on Water Pollution Research (IAWPR): Copenhagen, Denmark, 1977; pp. 183-193.

13. Ward, M.H.; Jones, R.R.; Brender, J.D.; De Kok, T.M.; Weyer, P.J.; Nolan, B.T.; Villanueva, C.M.; Van Breda, S.G. Drinking water nitrate and human health: An updated review. Int. J. Environ. Res. Public Health 2018, 15, 1557. [CrossRef] [PubMed]

14. Badeenezhad, A.; Radfard, M.; Abbasi, F.; Jurado, A.; Bozorginia, M.; Jalili, M.; Soleimani, H. Effect of land use changes on non-carcinogenic health risks due to nitrate exposure to drinking groundwater. Environ. Sci. Pollut. Res. 2021, $28,41937-41947$. [CrossRef] [PubMed]

15. Blaisdell, J.; Turyk, M.E.; Almberg, K.S.; Jones, R.M.; Stayner, L.T. Prenatal exposure to nitrate in drinking water and the risk of congenital anomalies. Environ. Res. 2019, 176, 108553. [CrossRef] [PubMed]

16. Barrett, J.H.; Parslow, R.C.; McKinney, P.A.; Law, G.R.; Forman, D. Nitrate in drinking water and the incidence of gastric, esophageal, and brain cancer in Yorkshire, England. Cancer Causes Control 1998, 9, 153-159. [CrossRef] [PubMed]

17. Jakszyn, P.; González, C.A. Nitrosamine and related food intake and gastric and oesophageal cancer risk: A systematic review of the epidemiological evidence. World J. Gastroenterol. 2006, 12, 4296. [CrossRef]

18. Cotruvo, J.A. 2017 WHO guidelines for drinking water quality: First addendum to the fourth edition. J.-Am. Water Work. Assoc. 2017, 109, 44-51. [CrossRef]

19. Badeenezhad, A.; Abbasi, F.; Shahsavani, S. Performance of household water desalinations devices and health risks assessment of fluorides $\left(\mathrm{F}^{-}\right)$and nitrate $\left(\mathrm{NO}^{-}\right)$in input and output water of the devices in Behbahan City southwest Iran. Hum. Ecol. Risk Assess. Int. J. 2019, 25, 217-229. [CrossRef]

20. Radfard, M.; Soleimani, H.; Azhdarpoor, A.; Faraji, H.; Mahvi, A.H. Dataset on assessment of physical and chemical quality of groundwater in rural drinking water, west Azerbaijan Province in Iran. Data Brief 2018, 21, 556-561. [CrossRef]

21. Azhdarpoor, A.; Radfard, M.; Pakdel, M.; Abbasnia, A.; Badeenezhad, A.; Mohammadi, A.A.; Yousefi, M. Assessing fluoride and nitrate contaminants in drinking water resources and their health risk assessment in a semiarid region of southwest Iran. Desalin. Water Treat. 2019, 149, 43-51. [CrossRef]

22. Darvishmotevalli, M.; Moradnia, M.; Noorisepehr, M.; Fatehizadeh, A.; Fadaei, S.; Mohammadi, H.; Salari, M.; Jamali, H.A.; Daniali, S.S. Evaluation of carcinogenic risks related to nitrate exposure in drinking water in Iran. MethodsX 2019, 6, 1716-1727. [CrossRef] [PubMed]

23. Machiwal, D.; Cloutier, V.; Güler, C.; Kazakis, N. A review of GIS-integrated statistical techniques for groundwater quality evaluation and protection. Environ. Earth Sci. 2018, 77, 681. [CrossRef]

24. Giri, S.; Tiwari, A.K.; Mahato, M.K.; Singh, A.K. Integrated approaches to identify the major controlling factors of groundwater chemistry and quality assessment for suitability of different uses in West Singhbhum, India. Environ. Earth Sci. 2021, 80, 756. [CrossRef]

25. Safa, O.; Soltanipoor, M.A.; Rastegar, S.; Kazemi, M.; Dehkordi, K.N.; Ghannadi, A. An ethnobotanical survey on hormozgan province, Iran. Avicenna J. Phytomed. 2013, 3, 64.

26. Bazrafshan, O.; Parandin, F.; Farokhzadeh, B. Assessment of hydro-meteorological drought effects on groundwater resources in Hormozgan region-South of Iran. Ecopersia 2016, 4, 1569-1584. [CrossRef]

27. Keramati, H.; Miri, A.; Baghaei, M.; Rahimizadeh, A.; Ghorbani, R.; Fakhri, Y.; Bay, A.; Moradi, M.; Bahmani, Z.; Ghaderpoori, M.; et al. Fluoride in Iranian Drinking Water Resources: A Systematic Review, Meta-analysis and Non-carcinogenic Risk Assessment. Biol. Trace Elem. Res. 2019, 188, 261-273. [CrossRef] [PubMed]

28. Sadeghi, F.; Nasseri, S.; Yunesian, M.; Nabizadeh, R.; Mosaferi, M.; Mesdaghinia, A. Carcinogenic and non-carcinogenic risk assessments of arsenic contamination in drinking water of Ardabil city in the Northwest of Iran. J. Environ. Sci. Health Part A 2018, 53, 421-429. [CrossRef]

29. Mustaffa, A.R.; Ku Hamid, K.H.; Musa, M.; Idris, J.; Ramli, R. High Nitrate and Phosphate Ions Reduction in Modified Low Salinity Fresh Water through Microalgae Cultivation. Processes 2019, 7, 129. [CrossRef] 
30. Ashbolt, N.J.; Amézquita, A.; Backhaus, T.; Borriello, P.; Brandt, K.K.; Collignon, P.; Coors, A.; Finley, R.; Gaze, W.H.; Heberer, T. Human health risk assessment (HHRA) for environmental development and transfer of antibiotic resistance. Environ. Health Perspect. 2013, 121, 993-1001. [CrossRef]

31. Dehghani, M.; Mohammadpour, A.; Abbasi, A.; Rostami, I.; Gharehchahi, E.; Derakhshan, Z.; Ferrante, M.; Conti, G.O. Health risks of inhalation exposure to BTEX in a municipal wastewater treatment plant in Middle East city: Shiraz, Iran. Environ. Res. 2022, 204, 112155. [CrossRef]

32. Smith, R.L. EPA Region III Risk Based Concentration Table; Environmental Protection Agency: Washington, DC, USA, $1995 ;$ pp. 1-24.

33. Golaki, M.; Azhdarpoor, A.; Mohamadpour, A.; Derakhshan, Z.; Conti, G.O. Health risk assessment and spatial distribution of nitrate, nitrite, fluoride, and coliform contaminants in drinking water resources of kazerun, Iran. Environ. Res. 2022, $203,111850$. [CrossRef] [PubMed]

34. Mohammadpour, A.; Tabatabaee, Z.; Dehbandi, R.; Khaksefidi, R.; Golaki, M.; Gharechahi, E.; Samaei, M.R.; Mohammadpour, R.; Sheibani, A.; Badeenezhad, A. Concentration, distribution and probabilistic health risk assessment of exposure to fluoride in drinking water of Hormozgan province, Iran. Stoch. Environ. Res. Risk Assess. 2021. [CrossRef]

35. Dehghani, M.; Gharehchahi, E.; Jafari, S.; Moeini, Z.; Derakhshan, Z.; Ferrante, M.; Conti, G.O. Health risk assessment of exposure to atrazine in the soil of Shiraz farmlands, Iran. Environ. Res. 2022, 204, 112090. [CrossRef] [PubMed]

36. Fitzpatrick, J.; Schoeny, R.; Gallagher, K.; Deener, K.; Dockins, C.; Firestone, M.; Jordan, W.; McDonough, M.; Murphy, D.; Olsen, M.; et al. US Environmental Protection Agency's framework for human health risk assessment to inform decision making. Int. J. Risk Assess. Manag. 2017, 20, 3-20. [CrossRef]

37. Tirkey, P.; Bhattacharya, T.; Chakraborty, S.; Baraik, S. Assessment of groundwater quality and associated health risks: A case study of Ranchi city, Jharkhand, India. Groundw. Sustain. Dev. 2017, 5, 85-100. [CrossRef]

38. Dehghani, M.; Shahsavani, S.; Mohammadpour, A.; Jafarian, A.; Arjmand, S.; Rasekhi, M.A.; Dehghani, S.; Zaravar, F.; Derakhshan, Z.; Ferrante, M.; et al. Determination of chloroform concentration and human exposure assessment in the swimming pool. Environ. Res. 2022, 203, 111883. [CrossRef]

39. Giri, S.; Singh, A.K.; Mahato, M.K. Monte Carlo simulation-based probabilistic health risk assessment of metals in groundwater via ingestion pathway in the mining areas of Singhbhum copper belt, India. Int. J. Environ. Health Res. 2020, 30, 447-460. [CrossRef]

40. Mukherjee, I.; Singh, U.K.; Singh, R.P.; Kumari, D.; Jha, P.K.; Mehta, P. Characterization of heavy metal pollution in an anthropogenically and geologically influenced semi-arid region of east India and assessment of ecological and human health risks. Sci. Total Environ. 2020, 705, 135801. [CrossRef]

41. Mirzaei, M. Concentrations of Nitrate groundwater in the 17 Wells at the Region of Hasht Bandi of Minab, Iran. IOSR J. Environ. Sci. Toxicol. Food Technol. 2015, 9, 59-63.

42. Hourieh Fallah, S.; Bakaeian, M.; Parsian, H.; Amouei, A.; Asgharnia, H.; Ghanbarian, M.; Mousapour, A.; Tabarinai, H.; Oskoei, V.; Miri, S.A. Potentially harmful heavy metal contamination in Babolrood river: Evaluation for risk assessment in the Mazandaran province, Iran. Int. J. Environ. Anal. Chem. 2020, 1-15. [CrossRef]

43. Qasemi, M.; Farhang, M.; Biglari, H.; Afsharnia, M.; Ojrati, A.; Khani, F.; Samiee, M.; Zarei, A. Health risk assessments due to nitrate levels in drinking water in villages of Azadshahr, northeastern Iran. Environ. Earth Sci. 2018, 77, 782. [CrossRef]

44. Sadler, R.; Maetam, B.; Edokpolo, B.; Connell, D.; Yu, J.; Stewart, D.; Park, M.J.; Gray, D.; Laksono, B. Health risk assessment for exposure to nitrate in drinking water from village wells in Semarang, Indonesia. Environ. Pollut. 2016, 216, 738-745. [CrossRef] [PubMed]

45. Gholami, Z.; Abtahi, M.; Golbini, M.; Parseh, I.; Alinejad, A.; Avazpour, M.; Moradi, S.; Fakhri, Y.; Mousavi Khaneghah, A. The concentration and probabilistic health risk assessment of nitrate in Iranian drinking water: A case study of Ilam city. Toxin Rev. 2019, 40, 1048-1057. [CrossRef]

46. Barry, K.H.; Jones, R.R.; Cantor, K.P.; Beane Freeman, L.E.; Wheeler, D.C.; Baris, D.; Johnson, A.T.; Hosain, G.M.; Schwenn, M.; Zhang, H.; et al. Ingested Nitrate and Nitrite and Bladder Cancer in Northern New England. Epidemiology 2020, 31, 136-144. [CrossRef]

47. Temkin, A.; Evans, S.; Manidis, T.; Campbell, C.; Naidenko, O.V. Exposure-based assessment and economic valuation of adverse birth outcomes and cancer risk due to nitrate in United States drinking water. Environ. Res. 2019, 176, 108442. [CrossRef] [PubMed]

48. Soleimani, H.; Nasri, O.; Ghoochani, M.; Azhdarpoor, A.; Dehghani, M.; Radfard, M.; Darvishmotevalli, M.; Oskoei, V.; Heydari, M. Groundwater quality evaluation and risk assessment of nitrate using monte carlo simulation and sensitivity analysis in rural areas of Divandarreh County, Kurdistan province, Iran. Int. J. Environ. Anal. Chem. 2020, 1-19. [CrossRef]

49. Sakizadeh, M.; Zhang, C. Health risk assessment of nitrate using a probabilistic approach in groundwater resources of western part of Iran. Environ. Earth Sci. 2020, 79, 43. [CrossRef]

50. Qasemi, M.; Afsharnia, M.; Farhang, M.; Ghaderpoori, M.; Karimi, A.; Abbasi, H.; Zarei, A. Spatial distribution of fluoride and nitrate in groundwater and its associated human health risk assessment in residents living in Western Khorasan Razavi, Iran. Desalin. Water Treat. 2019, 170, 176-186. [CrossRef] 
51. Jamshidi, A.; Morovati, M.; Golbini Mofrad, M.M.; Panahandeh, M.; Soleimani, H.; Abdolahpour Alamdari, H. Water quality evaluation and non-cariogenic risk assessment of exposure to nitrate in groundwater resources of kamyaran, iran: Spatial distribution, monte-carlo simulation, and sensitivity analysis. J. Environ. Health Sci. Engin. 2021, 19, 1117-1131. [CrossRef]

52. Shalyari, N.; Alinejad, A.; Hashemi, A.H.G.; RadFard, M.; Dehghani, M. Health risk assessment of nitrate in groundwater resources of Iranshahr using Monte Carlo simulation and geographic information system (GIS). MethodsX 2019, 6, $1812-1821$. [CrossRef] 